\title{
New Records of Commercially Valuable Black Corals (Cnidaria: Antipatharia) from the Northwestern Hawaiian Islands at Mesophotic Depths ${ }^{1}$
}

\author{
Daniel Wagner, ${ }^{2,8}$ Yannis P. Papastamatiou, ${ }^{3}$ Randall K. Kosaki, Kelly A. Gleason, ${ }^{4}$ \\ Greg B. McFall, ${ }^{5}$ Raymond C. Boland, ${ }^{6}$ Richard L. Pyle, ${ }^{7}$ and Robert 7. Toonen ${ }^{2}$
}

\begin{abstract}
Mesophotic coral reef ecosystems are notoriously undersurveyed worldwide and particularly in remote locations like the Northwestern Hawaiian Islands (NWHI). A total of 37 mixed-gas technical dives were performed to depths of $80 \mathrm{~m}$ across the NWHI to survey for the presence of the invasive octocoral Carijoa sp., the invasive red alga Acanthophora spicifera, and conspicuous megabenthic fauna such as black corals. The two invasive species were not recorded from any of the surveys, but two commercially valuable black coral species, Antipathes griggi and Myriopathes ulex, were found, representing substantial range expansions for these species. Antipathes griggi was recorded from the islands of Necker and Laysan in 58-70 m, and Myriopathes ulex was recorded from Necker Island and Pearl and Hermes Atoll in 58-70 m. Despite over $30 \mathrm{yr}$ of research in the NWHI, these black coral species had remained undetected. The new records of these conspicuous marine species highlight the utility of deepdiving technologies in surveying the largest part of the depth range of coral reef ecosystems (40-150 m), which remains largely unexplored.
\end{abstract}

The Papahānaumokuākea Marine $\mathrm{Na}$ tional Monument surrounding the North-

${ }^{1}$ This work was funded in part by the Western Pacific Fisheries Management Council to the University of Hawai'i through the NOAA Coral Reef Conservation Grant Program under award number NA07NMF4410114, NSF OCE-0623678, and NMSP MOA\#2005-008/66882. This is HIMB contribution 1395 and SOEST 7986. Manuscript accepted 30 July 2010.

${ }^{2}$ Hawai'i Institute of Marine Biology, Kāne'ohe, Hawai'i 96744.

${ }^{3}$ Florida Museum of Natural History, University of Florida, Gainesville, FL 32611.

${ }^{4}$ NOAA Papahānaumokuākea Marine National Monument, Honolulu, Hawai'i 96825.

${ }^{5}$ NOAA National Marine Sanctuary Program, Savannah, Georgia 31411.

${ }^{6}$ Pacific Islands Fisheries Science Center, National Marine Fisheries Service, Honolulu, Hawai'i 96822.

${ }^{7}$ Bernice P. Bishop Museum, Honolulu, Hawai'i 96817.

${ }^{8}$ Corresponding author (e-mail: wagnerda@hawaii .edu).

Pacific Science (2011), vol. 65, no. 2:249-255

doi: $10.2984 / 65.2 .249$

(C) 2011 by University of Hawai'i Press

All rights reserved western Hawaiian Islands (NWHI) represents the largest marine protected area under U.S. jurisdiction, encompassing over 351,000 $\mathrm{km}^{2}$ and spanning close to 2,000 $\mathrm{km}$ from Nìhoa Island to Kure Atoll. With the creation of the monument in 2006, there has been an increased emphasis on understanding what marine species live within the NWHI, as well as how these species may be connected to populations outside the monument. The coral fauna of these remote islands has previously been surveyed in shallow water $(<40 \mathrm{~m})$ using conventional scuba (Dana 1971, Grigg and Dollar 1980, Grigg 1981, Grigg et al. 1981, Coles 1998, Maragos et al. 2004), as well as in deep water $(100 \mathrm{~m}+)$ through the use of trawling (Nutting 1902, Grigg and Bayer 1976), deep-sea submersibles, and remotely operated vehicles (Baco 2007, Parrish and Baco 2007). However, as in many regions around the world, little is known about the coral fauna between these two depth ranges. This intermediate depth range hosts mesophotic coral reef ecosystems, which are light-dependent coral reef ecosystems found below conventional scuba diving limits of 30-40 m, and extending to the deepest portion of the euphotic 
zone, which may be over $150 \mathrm{~m}$ in some tropical and subtropical regions with high water clarity (Hinderstein et al. 2010, Kahng et al. 2010). These ecosystems are characterized by light-dependent corals and associated communities but frequently also include nonphotosynthetic organisms like sclerosponges, azooxanthellate gorgonians, and antipatharians (Kahng et al. 2010). Mesophotic coral reef ecosystems are notoriously undersurveyed worldwide (Kahng et al. 2010) and particularly in remote locations like the NWHI (Rooney et al. 2010). In August 2009, mixedgas technical diving was used for the first time to systematically survey the NWHI fauna below conventional scuba depths (>40 m). The primary objective of the mission was to survey for two invasive species that are abundant in the inhabited main Hawaiian Islands: the red alga Acanthophora spicifera and the octocoral Carijoa sp. (Kahng 2006, See et al. 2009). Acanthophora spicifera has previously been sighted in the NWHI off Midway Atoll (See et al. 2009); however, Carijoa sp. has not yet been reported in any of the surveys from the NWHI (Kahng 2006, See et al. 2009). Special emphasis was placed on surveying for conspicuous megabenthic fauna such as black corals because their habitat requirements are similar to those of the invasive octocoral Carijoa sp. in the main Hawaiian Islands (Grigg 2003, Kahng and Grigg 2005). Black corals are particularly important in Hawai' $i$ because they support commercial fisheries and as a result have been surveyed extensively, although historical surveys are restricted mainly to the main Hawaiian Islands (Grigg 1974, 1976, 2001, 2004, Parrish and Baco 2007). In addition, black corals constitute some of the major habitat-forming fauna on Hawaiian deep reefs and provide critical habitat for many species and associates (Grigg 1964, Barnard 1971, Castro 1971, Montgomery 2002, Boland and Parrish 2005).

\section{MATERIALS AND METHODS}

All surveys were performed using open-circuit trimix technical diving on a research expedition to the NWHI aboard R/V Hi ialakai (HA-09-06, 8 August 2009-6 September
2009). Dive sites were chosen using multibeam and side-scan sonar data collected by the R/V Hi ialakai. Chosen areas contained steep vertical drop-offs and hard substrate in depths of 50-80 $\mathrm{m}$, which are the typical habitat requirements for Carijoa sp. (Kahng 2006), as well as several antipatharian species in Hawai'i (Grigg and Opresko 1977, Grigg 1993, Parrish and Baco 2007). A total of 37 dives was conducted off Ni'ihau, Nīhoa, Necker, Laysan, Pearl and Hermes, Midway, and Kure (see Figure 1) to maximum depths of $80 \mathrm{~m}$, with bottom times ranging from 15 to $25 \mathrm{~min}$. During surveys divers swam in the direction of the prevailing current and sampled antipatharian colonies in their immediate vicinity. The latitude/longitude position of the start and end of each surveyed site was obtained through a GPS receiver attached to a surface float towed by divers. The size of surveyed area of each dive was estimated by assuming that individual divers were spaced 5 $\mathrm{m}$ apart and covered average areas of $64 \mathrm{~m}^{2}$ per dive (range: 5-198 $\mathrm{m}^{2}$ ). All sampled antipatharian colonies were photographed in situ, and samples consisting of branches 3-5 $\mathrm{cm}$ long were clipped from each colony and preserved in $10 \%$ formaldehyde in seawater. Samples were prepared for scanning electron microscopy (SEM) of skeletal spines using the methods of Wagner et al. (2010) and compared with antipatharian collections from Hawai' $i$ housed at the National Museum of Natural History, Smithsonian Institution, in Washington, D.C., and the Bernice P. Bishop Museum in Honolulu.

\section{RESULTS AND DISCUSSION}

The octocoral Carijoa sp. and the red alga $A$. spicifera, which are both considered invasive in the main Hawaiian Islands (Kahng 2006, See et al. 2009), were not recorded at any of the surveyed sites (Figure 1). Two commercially valuable antipatharian species were recorded from mesophotic depths in the NWHI for the first time: Antipathes griggi Opresko, 2009 (Figure 2) from the islands of Necker and Laysan in 58-70 m, and Myriopathes ulex (Ellis \& Solander, 1786) (Figure 3) from Necker Island and Pearl and Hermes Atoll in 58-70 m. 


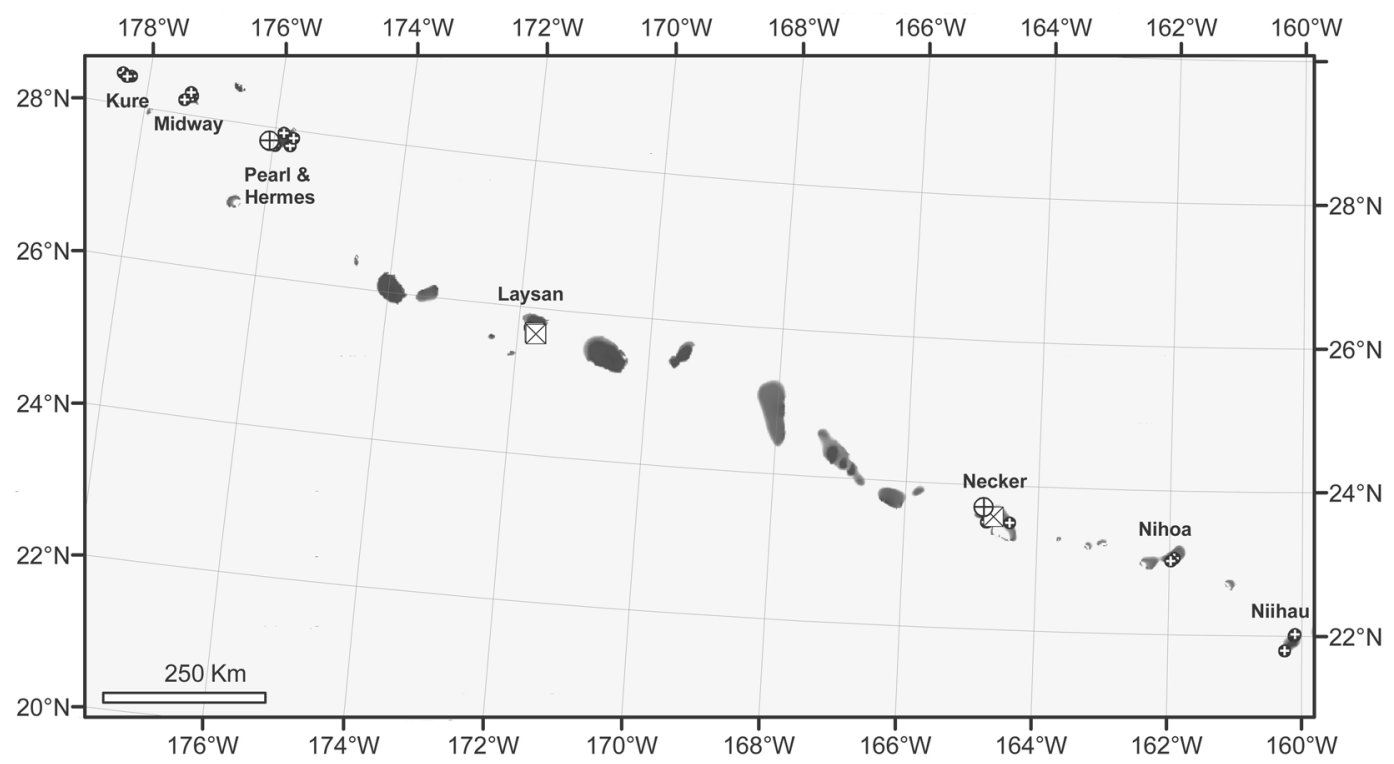

Figure 1. Map of sites surveyed for black corals using mixed-gas technical diving as part of surveys for the invasive species Carijoa sp. and Acanthophora spicifera in the NWHI (black circle, surveyed site; white square, Antipathes griggi recorded; white circle, Myriopathes ulex recorded).

The densities of these two species were mostly low and varied between 0 and 0.047 colonies/ $\mathrm{m}^{2}$ for $A$. griggi and 0 and 0.690 colonies $/ \mathrm{m}^{2}$ for $M$. ulex. Before this, only seven antipatharian species were recorded from the NWHI: (1) a Cirrbipathes sp. sighted off Nihoa and French Frigate Shoals down to a depth of 20 m (Maragos et al. 2004), (2) an unidentified species similar to Antipathes griggi sighted off Brooks Banks below 90 m (Grigg 1974), (3) Myriopathes ulex collected off Brooks Banks in 216-330 m (Grigg and Opresko 1977), (4) Acanthopathes undulata collected off Brooks Banks in 384-432 m (Grigg and Opresko 1977), (5) an undescribed Antipathes sp. collected off French Frigate Shoals and Brooks Banks in 353-430 m (Grigg and Opresko 1977), (6) Dendropathes bacotaylorae collected off Twin Banks in $408 \mathrm{~m}$ (Opresko 2005), and (7) Umbellopathes helioanthes collected off Laysan in 1,205-1,383 m (Opresko 2005). However, the scarcity of antipatharian records from the NWHI is likely a result of the low sampling effort in this remote region, because many antipatharian species are widely distributed along the Hawaiian Archipelago
(Grigg and Opresko 1977, Parrish and Baco 2007).

The new record of Antipathes griggi from the islands of Necker and Laysan (Figure 1) is the first report of this species north of $\mathrm{Ni}^{\text {' } i h a u ~}$ (Grigg and Opresko 1977). This Hawaiian antipatharian species was previously identified as A. dichotoma (Pallas 1776, Bayer 1961), a species originally described from the Mediterranean Sea (Opresko 2003). In 2009, comparisons of Hawaiian specimens with those found in the Mediterranean Sea revealed substantial morphological differences, and as a result the Hawaiian " $A$. dichotoma" was assigned the new name of $A$. griggi (Opresko 2009). Antipathes griggi is the main species targeted by the Hawaiian black coral fishery (Grigg 1993, 2001, 2004, Parrish and Baco 2007), and therefore surveys for this species have been numerous in the main Hawaiian Islands, where it is reported from the islands of Hawai'i to Ni'ihau at depths of 35-110 m (Grigg 1976, 2001, 2004, Grigg and Opresko 1977, Opresko 2009). Here we extend the known geographic distribution of the commercially valuable black coral species $A$. griggi 


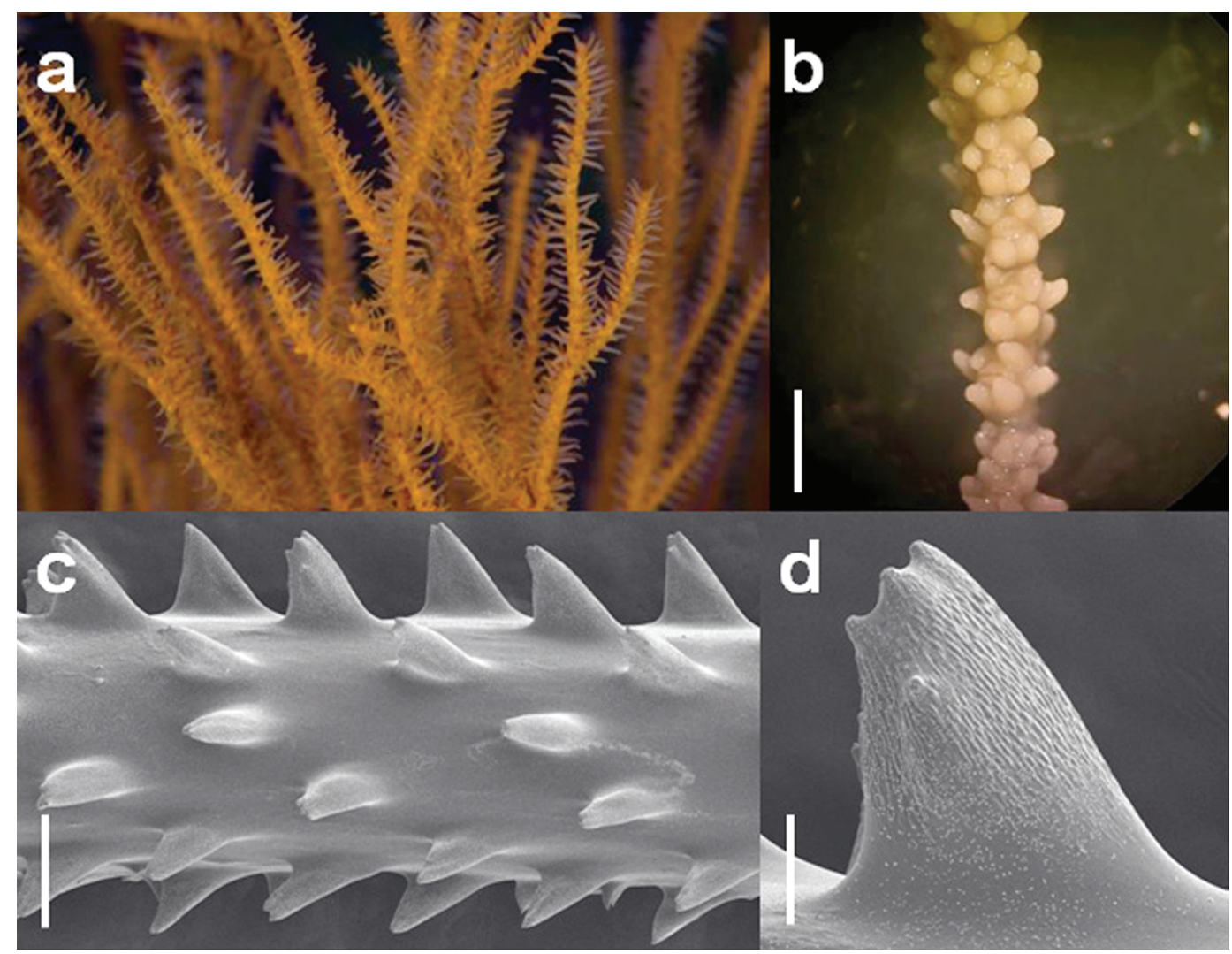

FIGURE 2. Antipathes griggi: (a) in situ photograph of colony off Laysan Island at $58 \mathrm{~m}$; $(b)$ preserved polyp close-up (scale bar = $2 \mathrm{~mm}$ ); (c) scanning electron micrograph of terminal branch (scale bar $=200 \mu \mathrm{m}) ;(d)$ scanning electron micrograph of polypar spine (scale bar $=50 \mu \mathrm{m})$.

to the NWHI of Necker $\left(23^{\circ} 38.014^{\prime} \mathrm{N}\right.$, $164^{\circ} 44.491^{\prime} \mathrm{W}, 58 \mathrm{~m}$ ) and Laysan $\left(25^{\circ}\right.$ $43.568^{\prime} \mathrm{N}, 171^{\circ} 49.450^{\prime} \mathrm{W}, 58 \mathrm{~m} ; 25^{\circ}$ $42.572^{\prime} \mathrm{N}, 171^{\circ} 48.357^{\prime} \mathrm{W}, 59 \mathrm{~m} ; 25^{\circ}$ $\left.42.632^{\prime} \mathrm{N}, 171^{\circ} 48.596^{\prime} \mathrm{W}, 70 \mathrm{~m}\right)$, representing a range expansion of over $1,250 \mathrm{~km}$ to the northwest. The fact that the first dive mission to ever survey this area found this conspicuous black coral species at two islands separated by a large distance, suggests that it may also be present in other locations.

Myriopathes ulex (formerly Antipathes ulex) is also commercially harvested in Hawai' $i$ (Grigg 1993, Parrish and Baco 2007), although it is rare at the $40-75 \mathrm{~m}$ depths where black coral is currently harvested (Grigg 2001, Boland and Parrish 2005, Parrish and Baco
2007). This species has recently been reassigned to the newly created antipatharian family Myriopathidae and genus Myriopathes (Opresko 2001). Myriopathes ulex was originally described from Indonesia (Ellis and Solander 1786) but subsequently reported from throughout the Indo-Pacific (Gray 1857, Brook 1889, Van Pesch 1914, Grigg and Opresko 1977, Colin and Arneson 1995, Chave and Malahoff 1998, Parrish and Baco 2007, Rogers et al. 2007, Bo 2008, Moon and Song 2008). Unfortunately, the original species description is brief, and the type material is lost (D. Opresko, pers. comm.); therefore, the true geographic distribution of this species will be uncertain until a neotype is designated and a thorough taxonomic study is 


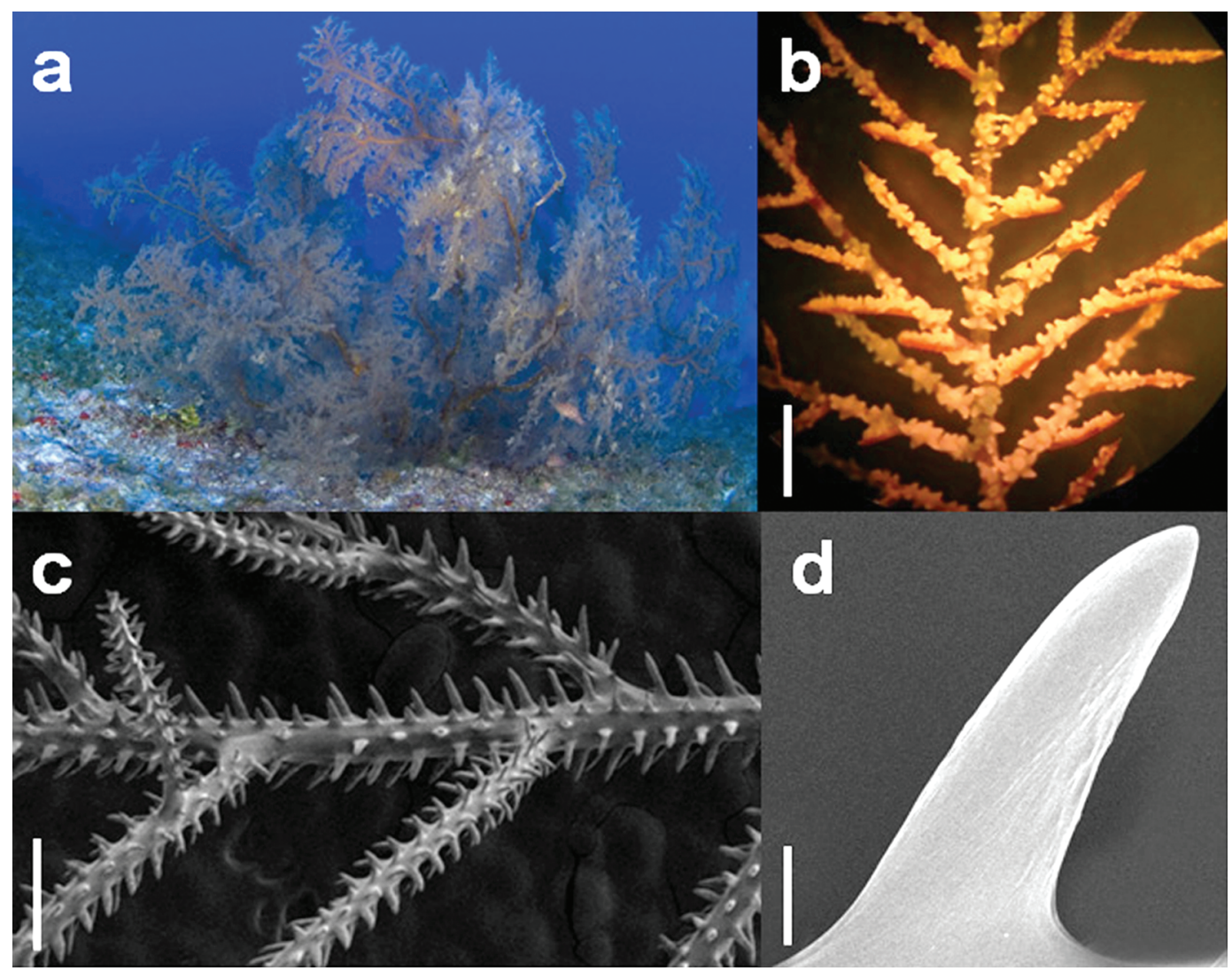

Figure 3. Myriopathes ulex: (a) in situ photograph of colony off Pearl and Hermes Atoll at $61 \mathrm{~m} ;(b)$ preserved polyp close-up (scale bar $=2 \mathrm{~mm}) ;(c)$ scanning electron micrograph of terminal branch (scale bar $=400 \mu \mathrm{m}) ;(d)$ scanning electron micrograph of polypar spine (scale bar $=20 \mu \mathrm{m})$.

undertaken. The morphology of the corallum and skeletal spines of specimens collected as part of this study (Figure 3) are very similar to those of other M. ulex specimens previously collected from around Hawai' $i$. We therefore continue to use the previously published name of $M$. ulex here, pending future taxonomic surveys. Grigg and Opresko (1977) reported this species in the main Hawaiian Islands at depths between 30 and $50 \mathrm{~m}$, as well as in the NWHI around Brooks Banks at depths between 216 and $330 \mathrm{~m}$. In other Indo-Pacific locations M. ulex has been reported as shallow as $25 \mathrm{~m}$ off Korea (Moon and Song 2008) and as deep as $364 \mathrm{~m}$ in the central Pacific (Chave and Malahoff 1998). Here we extend the range of this species in the Hawaiian Islands to include Necker Island $\left(23^{\circ} 38.019^{\prime} \mathrm{N}, 164^{\circ}\right.$ $44.470^{\prime} \mathrm{W}, 58 \mathrm{~m}$ ) and Pearl and Hermes Atoll $\left(27^{\circ} 45.716^{\prime} \mathrm{N}, 175^{\circ} 58.983^{\prime} \mathrm{W}, 61 \mathrm{~m} ; 27^{\circ}\right.$ $45.827^{\prime} \mathrm{N}, 175^{\circ} 59.161^{\prime} \mathrm{W}, 70 \mathrm{~m}$ ) (Figure 1), thus extending the geographic range of this species over $1,020 \mathrm{~km}$ to the northwest.

Coral reef ecosystems below the depth limits of traditional scuba diving remain scarcely surveyed worldwide and particularly in remote regions like the NWHI. The substantial range expansions of conspicuous marine species like those of the black corals $A$. griggi and $M$. ulex reported here, emphasize the value of deep-diving technologies in surveying the largest portion of the depth range of coral reef ecosystems (40-150 m), which remains largely unexplored. 


\section{ACKNOWLEDGMENTS}

We thank Dennis Opresko for taxonomic assistance, and Tina Carvalho and Scott Whittaker for help in performing the SEM analysis. Special thanks to the captain and crew of R/V Hi ialakai, who provided surface support for all field operations.

\section{Literature Cited}

Baco, A. R. 2007. Exploration for deep-sea corals on North Pacific seamounts and islands. Oceanography 20 (4): 108-117.

Barnard, J. L. 1971. Key to the Hawaiian marine Gammaridea, 0-30 meters. Smithson. Contrib. Zool. 58:1-135.

Bayer, F. M. 1961. Summary of black coral investigations to date. Hawaii. Shell News 9 (12): 8.

Bo, M. 2008. Taxonomy and ecology of antipatharians. Ph.D. diss., Universita Politecnica Delle Marche, Ancona.

Boland, R. C., and F. A. Parrish. 2005. A description of fish assemblages in the black coral beds off Lahaina, Maui, Hawai'i. Pac. Sci. 59:411-420.

Brook, G. 1889. Report on the Antipatharia. Rep. Sci. Res. Voy. H.M.S. Chall. Zool. 32 (80): 1-222.

Castro, P. 1971. The natantian shrimps (Crustacea, Decapoda) associated with invertebrates in Hawaii. Pac. Sci. 25:395-403.

Chave, E. H., and A. Malahoff. 1998. In deeper waters: Photographic studies of Hawaiian deep-sea habitats and life-forms. University of Hawai'i Press, Honolulu.

Coles, S. L. 1998. First record of the reef coral Montipora turgescens Bernard 1897 in Hawai'i (Cnidaria: Anthozoa: Scleractinia). Bishop Mus. Occas. Pap. 56:60-62.

Colin, P. L., and C. Arneson. 1995. Tropical Pacific invertebrates: A field guide to the marine invertebrates occurring on tropical Pacific coral reefs, seagrass beds and mangroves. Coral Reef Press, Beverly Hills.

Dana, J. D. 1846. Zoophytes. United States Exploring Expedition 7: $741 \mathrm{pp}$.

Dana, T. F. 1971. On the reef corals of the world's most northern atoll (Kure: Hawaiian Archipelago). Pac. Sci. 25:80-87.
Ellis, J., and D. Solander. 1786. The natural history of many curious and uncommon zoophytes collected by the late John Ellis, systematically arranged and described by the late Daniel Solander. London.

Gray, J. E. 1857. Synopsis of the families and genera of axiferous zoophytes or barked corals. Proc. Zool. Soc. Lond. 25:278-294.

Grigg, R. W. 1964. A contribution to the biology and ecology of the black coral, Antipathes grandis in Hawaii. M.S. thesis, University of Hawai'i at Mānoa, Honolulu.

- 1974. Distribution and abundance of precious corals. Proc. 2nd Int. Coral Reef Symp. 2:235-240.

- 1976. Fishery management of precious and stony corals in Hawaii. UNIHISEAGRANT-TR-77-03.

. 1981. Acropora in Hawaii. Part 2. Zoogeography. Pac. Sci. 35:15-24.

- 1993. Precious coral fisheries of Hawai' $i$ and the U.S. Pacific islands. Mar. Fish. Rev. 55 (2): 50-60.

- 2001. Black coral: History of a sustainable fishery in Hawai'i. Pac. Sci. 55:291-299.

- 2003. Invasion of a deep coral bed by an alien species, Carijoa riisei of Maui, Hawai'i. Coral Reefs 22:121-122.

_ 2004. Harvesting impacts and invasion by an alien species decrease estimates of black coral yield off Maui, Hawai'i. Pac. Sci. 58:1-6.

Grigg, R. W., and F. M. Bayer. 1976. Present knowledge of the systematics and zoogeography of the order Gorgonacea in Hawai'i. Pac. Sci. 30:167-175.

Grigg, R. W., and S. J. Dollar. 1980. The status of reef studies in the Hawaiian Archipelago. Pages 100-120 in Proceedings of the Symposium on the Status of Resource Investigations in the Northwestern Hawaiian Islands. University of Hawai'i Sea Grant College Program Report, UNIHISEAGRANT-MR-80-04. Honolulu.

Grigg, R. W., and D. M. Opresko. 1977. Order Antipatharia, black corals. Pages 242-261 in D. M. Devaney and L. G. Eldredge, eds. Reef and shore fauna of Hawai'i. Section 1: Protozoa through Ctenophora. Bishop Museum Press, Honolulu. 
Grigg, R. W., J. Wells, and C. Wallace. 1981. Acropora in Hawaii. Part 1. History of the scientific record, systematics and ecology. Pac. Sci. 35:1-13.

Hinderstein, L. M., J. C. A. Marr, F. A. Martinez, M. J. Dowgiallo, K. A. Puglise, R. L. Pyle, D. G. Zawada, and R. Appeldoorn. 2010. Theme section on "mesophotic coral ecosystems: characterization, ecology, and management." Coral Reefs 29:247-251.

Kahng, S. E. 2006. Ecology and ecological impact of an alien octocoral, Carijoa riisei, in Hawai'i. Ph.D. diss., University of Hawai'i at Mānoa, Honolulu.

Kahng, S. E., J. R. Garcia-Sai, H. L. Spalding, E. Brokovish, D. Wagner, E. Weil, L. Hinderstein, and R. J. Toonen. 2010. Community ecology of mesophotic coral reef ecosystems. Coral Reefs 29:255-275.

Kahng, S. E., and R. W. Grigg. 2005. Impact of an alien octocoral, Carijoa riisei, on black corals in Hawaii. Coral Reefs 24:556-562.

Maragos, J. E., D. C. Potts, G. Aeby, D. Gulko, J. Kenyon, D. Siciliano, and D. VanRavenswaay. 2004. 2000-2002 rapid ecological assessment of corals (Anthozoa) on shallow reefs of the Northwestern Hawaiian Islands. Part 1: Species and distribution. Pac. Sci. 58:211-230.

Montgomery, A. D. 2002. The feasibility of transplanting black coral (order Antipatharia). Hydrobiologia 471:157-164.

Moon, H. W., and J. I. Song. 2008. Taxonomy of the black coral family Myriopathidae (Anthozoa: Antipatharia) from Korea. Korean J. Syst. Zool. 24:251-263.

Nutting, C. C. 1902. Descriptions of the Alcyonaria collected by the U.S. Bureau of Fisheries Steamer Albatross in the vicinity of the Hawaiian Islands in 1902. Proc. U.S. Natl. Mus. 34:543-601.

Opresko, D. M. 2001. Revision of the Antipatharia (Cnidaria: Anthozoa). Part I. Establishment of a new family, Myriopathidae. Zool. Meded. (Leiden) 75 (17): 343-370. . 2003. Redescription of Antipathes dichotoma Pallas, 1766 (Cnidaria: Anthozoa: Antipatharia). Zool. Meded. (Leiden) 77:481-493.
2005. New genera and species of antipatharian corals (Cnidaria: Anthozoa) from the North Pacific. Zool. Meded. (Leiden) 79-2 (7): 129-165.

. 2009. A new name for the Hawaiian antipatharian coral formerly known as $A n$ tipathes dichotoma (Cnidaria: Anthozoa: Antipatharia). Pac. Sci. 63:277-291.

Parrish, F. A., and A. R. Baco. 2007. State of deep coral ecosystems in the U.S. Pacific islands region: Hawai' $i$ and the U.S. Pacific territories. Pages 159-194 in S. E. Lumsden, T. F. Hourigan, A. W. Bruckner, and G. Dorr, eds. The state of deep coral ecosystems in the United States. NOAA Tech. Memo. CRCP-3.

Rogers, A. D., A. Baco, H. Griffiths, T. Hart, and J. M. Hall-Spencer. 2007. Corals on seamounts. Supplementary material (including Appendix 8.1). Pages 141-160 in T. J. Pitcher, T. Morato, P. J. B. Hart, M. R. Clark, N. Haggan, and R. S. Santos, eds. Seamounts: Ecology, conservation and management. Fish and Aquatic Resources Series, Blackwell, Oxford.

Rooney, J., E. Donham, A. Montgomery, H. Spalding, F. Parrish, R. Boland, D. Fenner, J. Gove, and O. Vetter. 2010. Mesophotic coral ecosystems in the Hawaiian Archipelago. Coral Reefs 29:361-367.

See, K., S. Godwin, and C. Menza. 2009. Nonindigenous and invasive species. Pages 275-290 in A. Friedlander, K. Keller, L. Wedding, A. Clarke, and M. Monaco, eds. A marine biogeographic assessment of the Northwestern Hawaiian Islands. NOAA Tech. Memo. NOS NCCOS 84.

Van Pesch, A. J. 1914. The Antipatharia of the Siboga Expedition. Sib. Exp. Monogr. 17:1-258.

Wagner, D., M. R. Brugler, D. M. Opresko, S. C. France, A. M. Montgomery, and R. J. Toonen. 2010. Using morphometrics, in situ observations and genetic characters to distinguish among commercially valuable Hawaiian black coral species; a redescription of Antipathes grandis Verrill, 1928 (Antipatharia: Antipathidae). Invertebr. Syst. 24:271-290. 
